\title{
The Comparison of Self-regulation and Affective Control in Methampheta- mine and Narcotics Addicts and Non-Addicts
}

\author{
Kolthoum Tayyebi ${ }^{1,}$, Abbas Abolghasemi ${ }^{2}$, Majid Mahmood Alilu ${ }^{3}$, Nader Monirpoor ${ }^{4}$ \\ ${ }^{1}$ Department of Clinical Psychology, Islamic Azad University, Ardabil Branch, Ardabil, IR Iran \\ 2 Department of Psychology, University of Mohaghegh Ardabili, Ardabil, IR Iran \\ ${ }^{3}$ Department of Clinical Psychology, University of Tabriz, Tabriz, IR Iran \\ ${ }^{4}$ Department of Clinical Psychology, Islamic Azad University, Qom Branch, Qom, IR Iran \\ *Corresponding author: Kolthoum Tayyebi, Department of Clinical Psychology, Islamic Azad University, Ardabil Branch, Ardabil, IR Iran. Tel.: +98-9198865541, \\ Fax:+98-2517838014, E-mail:psyk13t@yahoo.com
}

\section{A B S T R A C T}

Background: Increased prevalence and widespread use of methamphetamine is the public challenge and worry in the world. It seems that low levels of self-regulation and affective control to carry up probability of psychoactive drugs abuse.

objectives: The purpose of the present study is the comparison of self-regulation and affective control in methamphetamine and narcotics addicts and non-addicts.

Materials and Methods: In this causative-comparative study, 80 addicts (40 methamphetamine addicts and 40 narcotic addicts) who referred to self-reference quitting addictive centers in Miyaneh, Iran, participated in convenience sampling. Then, they matched up with 40 non-addicts according to age, sex, educational level, and marital status. To collect data, we used self-regulation questionnaire and affective control scale. The data was analyzed by multivariate analysis of variance (MANOVA) and LSD test.

Results: Result shows that there is a significant difference between methamphetamine addicts and narcotics addicts and non-addicts in selfregulation and affective control $(\mathrm{P}=0.001)$.

Conclusions: This finding indicates that low self-regulation and affective control is a risky factor in psychoactive drugs abuse.

Keywords: Narcotics; Methamphetamine; Self-regulation; Affective control

Copyright (@) 2013, NewPub.; Published by NewPub.

\section{Background}

The abuse of methamphetamine has increased worldwide in recent years, and methamphetamine use is often associated with psychological disorders (1). Therefore, researchers believe that self-regulation and self-control (and Affective control) can be affected by substance addicts' behaviors. Self-regulation, defined as the psych's efforts to control its internal states, processes and functions for the purpose of achieving a higher goal (2). Selfregulation is also the capacity to override one's thoughts, emotions, impulses, and automatic or habitual behav-

\footnotetext{
Article type: Research Article; Received: 06 Oct 2012, Revised: 22 Dec 2012, Accepted: 31 Dec 2012.
}

$\checkmark$ Implication for health policy/practice/research/medical education:

Also, these results have important implications on pathology, prevention and treatment of methamphetamine and narcotic addicts.

Please cite this paper as:

Tayyebi K, Abolghasemi A, Mahmood Alilu M, Monirpoor N. The Comparison of Self-regulation and Affective Control in Methamphetamine and Narcotics Addicts and Non-Addicts. Int J High Risk Behav Addict. 2013; 1(4): 172-7. DOI: 10.5812/ijhrba.8442 
iors. People must constantly adapt and adjust their behavior to new environments and demands by self-regulating. Furthermore, self-regulation influences many of the major problems faced by people as individuals and society as a whole. For instance, poor self-regulation can be very difficult to abstain from drug and alcohol use after one has established a routine of regular use. Therefore, self-regulation can allow individuals to resist drug abuse, and thereby reduce various problems associated with such abuse $(3,4)$. Also, it seems that self-regulation holds individual's behavior under the control of social standards. Behaviors that are rewarded in the society, can lead to the self-regulation (5). Therefore, when individuals use drugs, this rule is broken and drug use would reduce by addict's self-regulation (3). On the other hand, in every society, self-control and affective control is important for getting along with others. A person who cannot control his or her thoughts, feelings, or behavior is more likely to lash out in anger when frustrated, handle conflicts less constructively, engage in antisocial behavior (6); use drugs and commit substance-related problem behaviors presumably due to deficits in inhibitory control $(7,8)$. Copeland and Sorensen found that methamphetamine users were more likely to have a psychiatric diagnosis. Mood disorders accounted for $71 \%$ of the diagnoses among methamphetamine users (1). Sussman et al. have shown that behavioral self-control is inversely related to drug use, controlling for relatively unchangeable disorders of personality (9). Glassman et al. found that self-control strategies are associated with alcohol consumption and self-regulation is also related to alcohol problems (10). De wall et al. found that the capacity for self-control and self-regulation is a limited resource that operates like a strength or energy, and when this capacity is depleted, people are less successful in self-regulation and therefore they should be more likely to act aggressively if the aggressive impulse arises (11). Vik showed that there is a positive relation between female methamphetamine abusers and psychiatric disorders (anxiety disorder, depression and interpersonal sensitivity), so that 53\% of methamphetamine abusers had criteria for an affective disorder, and $46 \%$ of they had criteria for an anxiety disorder. (12). Results of a study by Otten et al. showed that low levels of self-control are predictive of co-occurrence of cannabis use and depressive symptoms. Also, this study showed that individuals with low self-control may be incapable of inhibiting impulsivity which is a sign for substance use (13). Study results of Cole et al. showed that affect, cognitive and behavior indicators of self-regulation were significant predictors of substance use disorder (2).

\section{Objectives}

Nowadays, there is an increasing tendency among youth to use methamphetamine, and few research works have been conducted on the importance of the self-reg- ulation and affective control skills of these groups; with emphasis on these findings, educational programs of self-regulation and affective control skills in therapeutic design in therapy centers could be applied. Therefore, the aim of this study is the comparison of self-regulation and affective control in methamphetamine and narcotics addicts and non-addicts.

\section{Materials and Methods}

\subsection{Participants and Plan}

In this causative-comparative study, 80 addicts (40 methamphetamine addicts and 40 narcotic addicts), who referred to self-reference quitting addictive centers in Miyaneh, Iran (2011), participated in the convenience sampling. Then, they were matched up with 40 non-addicts according to age, sex, educational level and marital status. The criteria of selected people included being: male, married, in the age range of 20 to 39 years, and literate. The criteria of exclusion were suffering from: psychotic disorders, bipolar or dissociative disorders; or a severe somatic disease.

\subsection{Measures}

\subsubsection{The Self-Regulation Questionnaire (SRQ)}

The questionnaire had 63 items; the subscales to measure the ability to develop, implement, and flexibility to maintain a planned behavior in order to achieve one's goals. Items were answered on a 5-point Likert scale with the following scale points (Strongly disagree, Disagree, Uncertain or Unsure, Agree and Strongly Agree). Scores above 239 indicate high (intact) self-regulation capacity; Scores of 214-238 indicate intermediate (moderate) self-regulation capacity, and scores less than 213 indicate low (impaired) self-regulation capacity. Reliability of the SRQ appears to be excellent. In a community sample of 83 people with varying levels of alcohol problem severity, the SRQ was administered twice, within 48 hours, to test the stability of scores it provides. Test-retest reliability for the total SRQ score was high $(\mathrm{r}=0.94, \mathrm{P}=0.001)$. The SRQ has also shown strong convergent validity with concomitant measures. In community sample Aubrey et al. (1994), SRQ score was significantly and inversely correlated with volume of alcohol consumption per occasion $(r=-0.23$, $\mathrm{P}=0.04)$ and with negative consequences of drinking $(\mathrm{r}=-0.46, \mathrm{P}=0.001)$. This means that people with lower scores on the SRQ were more likely to be heavy and problem drinkers (14). According to the Cronbach's alpha of this study for the whole scale, the reliability coefficient of internal consistency was 0.86 . Also, in the study of Tayyebi, a significant relationship was obtained between this questionnaire and Interpersonal Reactivity Index ( $\mathrm{r}$ 
$=+0.33 ; \mathrm{P}=0.01)(15)$.

\subsubsection{Affective Control Scale (ACS)}

This scale is designed by Williams and Chambless (1992) and it has 42 items and four subscales (Anger, Depressed Mood, Anxiety and Positive Affect). To obtain the overall scale score, first convert the responses of reverse worded items, and then compute the average of all 42 responses. Cronbach's Alpha in the study of Williams and Chambless (1992) was 0.94 in overall scale and varied from 0.72 to 0.91 in the subscales. Test-retest reliability for the total ACS score for two-week test-retest was 0.78 and in the subscales it varied from 0.66 to 0.77 . Also, Construct Validity- overall scale discriminant validity with MarlowCrowne Social Desirability Index obtained -0.17. Emotional Control Questionnaire convergent validity was $-0.72(P=0.001)(16)$. According to the Cronbach's alpha of this study for the whole scale, the reliability coefficient of internal consistency was obtained to be 0.81 . Also, in a study by Tayyebi, a significant relationship was obtained between this scale and Interpersonal Reactivity Index $(r=$ $-0.39 ; \mathrm{P}=0.01)(15)$.

\subsection{Procedure}

After selecting the research sample, the questionnaires were distributed to the subjects, and they were asked to complete the research instruments. The data was ana- lyzed by multivariate analysis of variance (MANOVA) and LSD test.

\section{Results}

The results show that $32 \%$ of methamphetamine addicts, $21 \%$ of narcotic addicts, and $40 \%$ of non-addicts covered an age range of $20-29$ years old. $68 \%$ of methamphetamine addicts, $79 \%$ of narcotic addicts, and $60 \%$ of non-addicts covered an age rang of 30-39 years old. Also, the results show that $68.6 \%$ of methamphetamine addicts, and $55.5 \%$ of narcotic addicts had precedent consecutive quitting. Table 1 shows the mean (and standard deviations) for self-regulation and affective control in methamphetamine addicts, narcotic addicts, and nonaddicts. Table 2 shows that significance tests of self-regulation and affective control permit use of multivariate variance analysis. These results demonstrate that there is a significant difference between at least one of the dependent variables. Eta square shows that there is significant differences between three groups overall, and the rate of the differences is $32 \%$ in self-regulation and $26 \%$ in the affective control. According to Leven test and its insignificance for all of variables, condition of equality is considered in variances of groups. According to Box test, it is not significant for any of variables, and this condition of equality is considered as variance matrices (selfregulation: $\mathrm{P}=0.26, \mathrm{~F}=1.69$, $\mathrm{Box}=93.35$; affective control: $\mathrm{P}=0.13, \mathrm{~F}=1.36$, Box $=28.77)$.

\begin{tabular}{|c|c|c|c|}
\hline Self-Regulation and Affective Control & $\begin{array}{l}\text { Methamphetamin Addicts, } \\
\text { Mean } \pm \text { SD }\end{array}$ & $\begin{array}{l}\text { Narcotics Addicts, } \\
\text { Mean } \pm \text { SD }\end{array}$ & $\begin{array}{l}\text { Non-Addicts, } \\
\text { Mean } \pm \text { SD }\end{array}$ \\
\hline \multicolumn{4}{|l|}{ Subscales of self-regulation } \\
\hline Receiving & $27.75 \pm 5.06$ & $31.69 \pm 5.83$ & $31.92 \pm 4.63$ \\
\hline Evaluating & $27.34 \pm 4.58$ & $27.89 \pm 3.67$ & $28.55 \pm 3.88$ \\
\hline Triggering & $28.87 \pm 3.7$ & $30.82 \pm 3.08$ & $31.12 \pm 3.67$ \\
\hline Searching & $29.58 \pm 4.55$ & $31.23 \pm 3.72$ & $32.12 \pm 3.04$ \\
\hline Formulating & $25.39 \pm 5.7$ & $28.74 \pm 4.63$ & $30.40 \pm 4.33$ \\
\hline Implementing & $27.31 \pm 4$ & $30.12 \pm 5.18$ & $32.60 \pm 4.08$ \\
\hline Assessing & $27.95 \pm 3.98$ & $29.10 \pm 3.43$ & $31.35 \pm 2.30$ \\
\hline Total & $194.22 \pm 18.67$ & $209.62 \pm 20.29$ & $218.08 \pm 14.56$ \\
\hline \multicolumn{4}{|l|}{ Subscales of affective control } \\
\hline Anger & $29.21 \pm 6.33$ & $33.69 \pm 6.03$ & $34.87 \pm 6.13$ \\
\hline Positive & $51.78 \pm 9.33$ & $57.84 \pm 7.89$ & $60.60 \pm 7.61$ \\
\hline Depression & $28.85 \pm 5.91$ & $33.84 \pm 5.67$ & $35.52 \pm 6.39$ \\
\hline Anxiety & $47.02 \pm 10.38$ & $58.23 \pm 11.57$ & $59.45 \pm 9.71$ \\
\hline Total & $144.32 \pm 15.69$ & $158.92 \pm 16.8$ & $160.25 \pm 16.86$ \\
\hline
\end{tabular}


Table 2. The significance Test of MANOVA for Subscales of Self-regulation and Affective Control

\begin{tabular}{|lllllll}
\hline & Value & F & Hypothesis Df & Error Df & Significance & Partial Eta Squared \\
\hline $\begin{array}{l}\text { Self-regulation } \\
\text { Pillai's Trace }\end{array}$ & 0.369 & 3.616 & 14 & & & \\
\hline Wilks' Lambda & 0.648 & 3.838 & 14 & 224 & 0.001 & 0.315 \\
\hline Hotelling' Trace & 0.517 & 4.060 & 14 & 222 & 0.001 & 0.315 \\
\hline Roy's Largest Root & 0.460 & 7.363 & 7 & 112 & 0.001 & 0.315 \\
\hline Affective control & & & & & 0.001 & 0.315 \\
\hline Pillai's Trace & 0.274 & 4.566 & 8 & 230 & 0.001 & 0.259 \\
\hline Wilks' Lambda & 0.730 & 4.860 & 8 & 228 & 0.001 & 0.259 \\
\hline Hotelling' Trace & 0.365 & 5.151 & 8 & 226 & 0.001 & 0.259 \\
\hline Roy's Largest Root & 0.349 & 10.039 & 8 & 115 & 0.001 & 0.259 \\
\hline
\end{tabular}

Table 3 shows that there are significant differences between methamphetamine and narcotic addicts and nonaddicts in the mean scores of Receiving $(\mathrm{F}=8.24)$, Triggering $(\mathrm{F}=4.9)$, Searching $(\mathrm{F}=4.58)$, Formulating $(\mathrm{F}=10.84)$, Implementing $(\mathrm{F}=14.32)$, and Effectiveness $(10.95)(\mathrm{P}=$ 0.001). While the results show that there is no difference between the three groups in the mean scores of Evaluating $(\mathrm{F}=0.89)$. Also, it can be concluded that there is significant difference between the three groups in the mean scores of Anger $(F=9.47)$, Positive affect $(F=11.9)$, Depres$\operatorname{sion}(\mathrm{F}=13.55)$, and Anxiety $(\mathrm{F}=17)(\mathrm{P}=0.001)$.

\begin{tabular}{|c|c|c|c|c|c|c|}
\hline Scales & $\begin{array}{l}\text { Dependent } \\
\text { Variable }\end{array}$ & SS & Df & MS & $\mathbf{F}$ & Significance \\
\hline \multirow[t]{7}{*}{ Self-regulation } & Receiving & 444.681 & 2 & 222.341 & 8.241 & 0.001 \\
\hline & Evaluating & 29.616 & 2 & 14.808 & 0.893 & 0.412 \\
\hline & Triggering & 120.483 & 2 & 60.241 & 4.907 & 0.009 \\
\hline & Searching & 134.617 & 2 & 67.309 & 4.581 & 0.012 \\
\hline & Formulating & 528.508 & 2 & 264.254 & 10.845 & 0.001 \\
\hline & Implementing & 556.155 & 2 & 283.077 & 14.32 & 0.001 \\
\hline & Assessing & 241.199 & 2 & 120.6 & 10.95 & 0.001 \\
\hline \multirow{4}{*}{$\begin{array}{l}\text { Affective con- } \\
\text { trol }\end{array}$} & Anger & 721.885 & 2 & 360.942 & 9.478 & 0.001 \\
\hline & Positive & 1651.890 & 2 & 825.945 & 11.907 & 0.001 \\
\hline & Depression & 977.026 & 2 & 488.513 & 13.55 & 0.001 \\
\hline & Anxiety & 3802.793 & 2 & 1901.396 & 17.006 & 0.001 \\
\hline
\end{tabular}

Abbreviations: SS; sum of squares, MS; mean square, F; f-ratio

According to Table 4, the results of LSD test for comparing the mean scores of subscales self-regulation demonstrate that methamphetamine addicts in comparison with narcotic addicts and methamphetamine addicts in comparison with non-addicts have lower mean scores in the Receiving, Triggering, Searching, and Formulating ( $P$ $=0.001$ ); methamphetamine addicts in comparison with narcotic addicts; methamphetamine addicts in comparison with non-addicts and narcotic addicts in comparison with non-addicts have lower mean scores for Imple- menting ( $\mathrm{P}=0.01)$; also, methamphetamine addicts in comparison with non-addicts and narcotic addicts in comparison with non-addicts have lower mean scores in the Effectiveness $(\mathrm{P}=0.001)$. Also, based on Table 5, results of LSD test for comparing the mean scores of subscales affective control depict that methamphetamine addicts in comparison with narcotic addicts; methamphetamine addicts in comparison with non-addicts have lower mean scores of Anger, Positive affect, Depression, and Anxiety (P $=0.001$ ). 


\begin{tabular}{|c|c|c|c|c|c|}
\hline Group & 2 & 3 & Group & 2 & 3 \\
\hline Receiving & & & Formulating & & \\
\hline $\begin{array}{l}\text { Methamphet- } \\
\text { amine addicts }\end{array}$ & $-3.93(0.001)$ & $-4.16(0.000)$ & $\begin{array}{l}\text { Methamphet- } \\
\text { amine addicts }\end{array}$ & $-3.35(0.003)$ & $5(0.000)$ \\
\hline Narcotic addicts & & $-0.23(0.843)$ & Narcotic addicts & _ & $-1.65(0.139)$ \\
\hline Non-addicts & $0.23(0.843)$ & & Non-addicts & $1.65(0.139)$ & \\
\hline Evaluating & & & Implementing & & \\
\hline $\begin{array}{l}\text { Methamphet- } \\
\text { amine addicts }\end{array}$ & $-0.55(0.543)$ & $-1.2(0.184)$ & $\begin{array}{l}\text { Methamphet- } \\
\text { amine addicts }\end{array}$ & $-2.81(0.006)$ & $-5.28(0.000)$ \\
\hline Narcotic addicts & & $-0.65(0.478)$ & Narcotic addicts & - & $-2.47(0.015)$ \\
\hline Non-addicts & $0.65(0.478)$ & & Non-addicts & $2.47(0.015)$ & \\
\hline Triggering & & & Assessing & & \\
\hline $\begin{array}{l}\text { Methamphet- } \\
\text { amine addicts }\end{array}$ & $-1.94(0.015)$ & $-2.24(0.005)$ & $\begin{array}{l}\text { Methamphet- } \\
\text { amine addicts }\end{array}$ & $-1.15(0.124)$ & $-3.39(0.000)$ \\
\hline Narcotic addicts & & $-0.3(0.700)$ & Narcotic addicts & & $-2.24(0.003)$ \\
\hline Non-addicts & $0.3(0.700)$ & & Non-addicts & $2.24(0.003)$ & \\
\hline Searching & & & Total & & \\
\hline $\begin{array}{l}\text { Methamphet- } \\
\text { amine addicts }\end{array}$ & $-1.64(0.057)$ & $-2.53(0.003)$ & $\begin{array}{l}\text { Methamphet- } \\
\text { amine addicts }\end{array}$ & $-15.39(0.000)$ & $-23.85(0.000)$ \\
\hline Narcotic addicts & & $-0.89(0.302)$ & Narcotic addicts & & $-8.45(0.039)$ \\
\hline Non-addicts & $0.89(0.302)$ & & Non-addicts & $8.45(0.039)$ & \\
\hline
\end{tabular}

Table 5. The LSD Test for the Comparison Mean Scores Subscales of Affective Control

\begin{tabular}{|c|c|c|c|c|c|}
\hline Group & 2 & 3 & Group & 2 & 3 \\
\hline Anger & & & Depression & & \\
\hline $\begin{array}{l}\text { Methamphet- } \\
\text { amine addicts }\end{array}$ & $-4.47(0.002)$ & $-5.65(0.000)$ & $\begin{array}{l}\text { Methamphet- } \\
\text { amine addicts }\end{array}$ & $-4.99(0.000)$ & $-6.67(0.000)$ \\
\hline Narcotic addicts & - & $-1.18(0.396)$ & Narcotic addicts & - & $-1.67(0.217)$ \\
\hline Non-addicts & $1.18(0.396)$ & - & Non-addicts & $1.67(0.217)$ & - \\
\hline Positive & & & Anxiety & & \\
\hline $\begin{array}{l}\text { Methamphet- } \\
\text { amine addicts }\end{array}$ & $-6.06(0.001)$ & $-8.81(0.000)$ & $\begin{array}{l}\text { Methamphet- } \\
\text { amine addicts }\end{array}$ & $-11.2(0.000)$ & $-12.42(0.000)$ \\
\hline Narcotic addicts & - & $-2.75(0.144)$ & Narcotic addicts & - & $-1.21(0.609)$ \\
\hline Non-addicts & $2.75(0.144)$ & - & Non-addicts & $-1.21(0.609)$ & - \\
\hline \multicolumn{6}{|l|}{ Total } \\
\hline $\begin{array}{l}\text { Methamphet- } \\
\text { amine addicts }\end{array}$ & $-14.6(0.000)$ & $-15.93(0.000)$ & & & \\
\hline Narcotic addicts & - & $-1.32(0.721)$ & & & \\
\hline Non-addicts & $1.32(0.721)$ & - & & & \\
\hline
\end{tabular}

\section{Discussion}

The aim of the current study was to compare self-regulation and affective control in methamphetamine and narcotic addicts and non-addicts. Results showed that there are significant differences between methamphetamine and narcotic addicts and non-addicts in self-regulation and affective control. In fact, the results showed that methamphetamine addicts in comparison with narcotics addicts and non-addicts; and narcotics addicts in comparison with non-addicts had lower self-regulation and affective control. These results are in line with the outcome of Sussman et al. (9), Salo et al. (17), Glassman et al. (10), Vik (12), Jensen-Campbell et al. (6), Gailiot et al. (3), Otten et al. (13), Cole et al. (2). From the viewpoint of 
the cognitive neuroscience researcher, deficits in regulation of cognition, emotion, or behavior, may depend on an individual's ability of determination when adaptive control is required (18). Therefore, it can be very difficult for drug addicts to abstain from drug use (3). Also, according to numerous studies, substance abuse and their influence on brain occur in complicated structures such as the prefrontal cortex, and structures that serve motivation, or the limbic system, to aim at individual's adaptive control and inhibit that substance addicts adapt and adjust effectively $(3,19)$. Therefore, substance addicts are involved in a recognition process of how to express and control their affects in the different situations, and defect in these skills influence different aspects of the personal life, interpersonal interaction, and mental and somatic health. Also, it is probable that substance addicts tend to act without thoughtfulness, which is an indicator of their low behavior control (9). Thus, as substance addicts cannot control thoughts, emotions, and behavior, if they encounter a defeat or anger they might avert conflicts and commit antisocial behaviors (6). In this way, they do not have successful interpersonal relationships (20). The findings presented in this study should be interpreted carefully. First, based on the self-reported scale and due to unconscious defense and prejudices in responses, the collected information brings about the possibility of information distortion. Second, addicts were selected only from one city and male addicts participated in this study; consequently, generalizations concerning self-regulation and affective control behaviors might be limited for other regions or the female addicts. Other limitations of the present study include the retrospective data collection and lack of follow-up information. Therefore, such studies should employ structured interviews and assess addiction symptoms and include an extended follow up period to track and examine relapse. Future research works should consider increasing the sample size and include both male and female addicts to test detailed hypotheses. Also, these results have important implications on pathology, prevention and treatment of methamphetamine and narcotic addicts.

\section{Acknowledgments}

The authors appreciate Dr. Hashemi, Dr. Behmanesh, Dr. Noorizadeh, Dr. Khodabandeh, and Mrs. Safaryani, and other employees of health and treatment center of Miyaneh for their helpful comments during the data collection.

\section{Authors' Contribution}

Kolsoum Tayyebi, Abbas Abolghasemi and Majid Mahmood Alilu designed, collected and analysed the data of the project. Nader Monirpoor have involved in writing this paper.

\section{Financial Disclosure}

None declared.

\section{Funding/Support}

This study was supported by the Department of Research and Training Drug Control Headquarters in Iran (grant 15/1120785).

\section{References}

1. Copeland AL, Sorensen JL. Differences between methamphetamine users and cocaine users in treatment. Drug Alcohol Depend.2001;62(1):91-5.

2. Cole J, Logan TK, Walker R. Social exclusion, personal control, selfregulation, and stress among substance abuse treatment clients. Drug Alcohol Depend.2011;113(1):13-20.

3. Gailliot MT, Mead NL, Baumeister RF, John OP, Robins RW, Rervin LA. Self-regulation. Hand book of personality theory and research. New York:The Guilford Press;2008. p. 472-91.

4. Wills TA, Sandy JM, Yaeger AM. Moderators of the relation between substance use level and problems: test of a self-regulation model in middle adolescence.J Abnorm Psychol.2002;111(1):3-21.

5. Baumeister RF, DeWall CN, Ciarocco NJ, Twenge JM. Social exclusion impairs self-regulation. J Pers Soc Psychol.2005;88(4):589-604.

6. Jensen Campbell LA, Knack JM, Waldrip AM, Campbell SD. Do big five personality traits associated with self-control influence the regulation of anger and aggression? JRes Pers.2007;41(2):403-24.

7. Vaughn MG, Beaver KM, DeLisi M, Perron BE, Schelbe L. Gene-environment interplay and the importance of self-control in predicting polydrug use and substance-related problems. Addict Behav.2009;34(1):112-6.

8. Coffey SF, Gudleski GD, Saladin ME, Brady KT. Impulsivity and rapid discounting of delayed hypothetical rewards in cocaine-dependent individuals. Exp Clin Psychopharmacol.2003;11(1):18-25.

9. Sussman S, McCuller WJ, Dent CW. The associations of social self-control, personality disorders, and demographics with drug use among high-riskyouth. Addict Behav.2003;28(6):1159-66.

10. Glassman T, Werch CC, Jobli E. Alcohol self-control behaviors of adolescents. Addict Behav.2007;32(3):590-7.

11. De Wall CN, Baumeister RF, Stillman TF, Gailliot MT. Violence restrained: effects of self-regulation and its depletion on aggression. JExp Soc Psychol.2007;43(1):62-76.

12. Vik PW. Methamphetamine use by incarcerated women: comorbid mood and anxiety problems. Womens Health Issues.2007;17(4):256-63.

13. Otten R, Barker ED, Maughan B, Arseneault L, Engels RC. Selfcontrol and its relation to joint developmental trajectories of cannabis use and depressive mood symptoms. Drug Alcohol Depend.2010;112(3):201-8.

14. Carey KB, Neal DJ, Collins SE. A psychometric analysis of the self-regulation questionnaire. Addict Behav.2004;29(2):253-60.

15. Tayyebi K. The comparison of self-regulation, affective control, and social deprivation in narcotics and psychoactive drugs addicts and normal personal. Ardabil: Islamic Azad University;2011.

16. Williams KE, Chambless DL. Affective Control Scale.1992.

17. Salo R, Nordahl TE, Natsuaki Y, Leamon MH, Galloway GP, Waters C, et al. Attentional control and brain metabolite levels in methamphetamine abusers. Biol Psychiatry.2007;61(11):1272-80.

18. Shiels K, Hawk LW. Self-regulation in ADHD: the role of error processing. Clin Psychol Rev.2010;30(8):951-61.

19. Robinson MD. Gassing, braking, and self-regulating: Error selfregulation, well-being, and goal-related processes. J Expe Social Psychol.2007;43(1):1-16.

20. Kokkonen M, Pulkkinen L. Emotion regulation strategies in relation to personality characteristics indicating low and high self-control of emotions. Pers Individ Dif.1999;27(5):913-32. 